УДК94:[070(477.41-21Переяслав)"19/20"

DO: 10.31470/2518-7600-2019-7-173-192

\title{
ВИДАННЯ ПЕРЕЯСЛАВЩИНИ: ІСТОРІЯ, РОЗВИТОК ТА ПЕРСПЕКТИВИ
}

\section{PERIODICALS OF PEREIASLAV DISTRICT: HISTORY, DEVELOPMENT AND PERSPECTIVES}

\section{Василь Холоденко,}

Аспірант 032 історія та археологія

holodenko-vasya@ukr.net

https://orcid.org/0000-0002-

3134-6421

ID: 0000-0002-3134-6421

ДВНЗ «Переяслав-

Хмельницький державний

педагогічний університет

імені Григорія Сковороди»,

м. Переяслав-Хмельницький, вул. Сухомлинського, 30,

Київська обл., Україна, 08401
Vasyl Kholodenko,

Postgraduate student 032

History and Archeology

holodenko-vasya@ukr.net

https://orcid.org/0000-0002-

3134-6421

ID: 0000-0002-3134-6421

SHEI «Pereiaslav-

Khmelnytskyi

Hryhorii Skovoroda State

Pedagogical University», 30,

Sukhomlynskoho Str.,

Pereiaslav-Khmelnytskyi,

Kyiv region, Ukraine, 08401

\section{ABSTRACT}

Periodicals are published at certain intervals with a predetermined permanent annual quantity and the title of numbered or dated, uniformly issued editions that are not repeated in content and have the same title. Particularly interesting for historians, especially for ethnographers, are regional periodicals. Such publications contain diverse information.

The purpose of this article is to analyze the historical stages of the development of periodicals of Pereiaslav district during almost a century'shistory, to outline the issue of the publication in all titles that have been changed six times, to make a general overview of newspapers according to reference literature and copies of newspapers.

To study the history and development of publications of Pereiaslav district during 20-the beginning of 21 century two main 
methods are used in the article: observation and description. At different stages of the study the method of functional analysis is used todetermine the thematic loading of periodicals.

In the process of research the following methods have been applied: the method of analysis and synthesis - at the stage of the text division of periodicals of Pereiaslav district and grouping them according to certain features; the method of quantitative analysis to determine the frequency of the use of headings and their various forms in the newspaper strips.

In general, during its existence the newspaper had six titles: 1925-1930 - «Zmytchka»; 1930-1941 - «Kolektyvist Pereiaslavshchyny»; 1943-1951 - «Prapor PereiaslavKhmelnytskoho»; 1951-1963 - «Zirka komunizmu»; 1963-1991 «Komunistychna Pratsia»; since 1991 - «Visnyk Pereiaslavshchyny».

It is concluded that the newspaper «Visnyk Pereiaslavshchyny» throughout almost a century's history stays a reliable source for study of social and political system, topics, printing and spelling fields, historical figures of Pereiaslav district and those who visited the area.

We, in the author's perspective, see the periodical sof Pereiaslav as a source of the history of Ukrainian archeology and not only.

Keywords: "Visnyk Pereiaslavshchyny», regional periodical, newspaper titles, newspaper publisher, journalist, public author.

Постановка проблеми. Періодичне видання - серіальне видання (зазвичай друковане), що виходить через певні проміжки часу, має заздалегідь визначену постійну щорічну кількість i назву нумерованих чи датованих, однотипово оформлених випусків, які не повторюються за змістом, мають однакову назву. Особливо цікаві для істориків, зокрема краєзнавців, регіональні видання. Такі видання містять низку різноманітної інформації.

Аналіз останніх досліджень і публікацій. Періодичні видання досліджувала низка вчених із журналістикознавства (А. Москаденко, В. Різун, В. Іванов та ін.), а саме видання Переяславщини вивчали В. Батрак, Г. Карпенко, М. Навальна, 
М. Пасенюк (Вісімдесят, 2005: 76). Але ці розвідки мали здебільшого оглядовий характер.

Мета статті - проаналізувати історичні етапи розвитку видання Переяславщини упродовж майже столітньої історії, окреслити вихід видання за всіма назвами, що змінювалася шість разів, зроблено загальний огляд газет за довідковою літературою та примірниками газет.

Методологія ведення дослідження. У статті для вивчення історії та розвитку видань Переяславщини упродовж XX - початку XXI ст. використано як основні метод спостереження та описовий метод. На різних етапах дослідження послуговувалися методом функціонального аналізу для визначення тематичного навантаження періодичних видань.

У процесі дослідження застосовано такі методи: метод аналізу та синтезу - на етапі членування текстів періодичного видання Переяславщини та групування їх за певними ознаками; метод квантитативного аналізу - задля визначення частотності використання рубрик і їх різноманітних форм в на газетних полосах.

Виклад основного матеріалу. Нині на теренах Переяславщини найтиражнішею $\epsilon$ газета «Вісник Переяславщини», яка має майже столітню історію.

«Вісник Переяславщини»

ПереяславХмельницька міськрайонна газета. Виходить 37 жовтня 1925 року два рази на тиждень у вівторок і п’ятницю. Реєстраційне свідоцтво КІ № 52 від 16 березня 1994 року. Розповсюджується в Переяслав-Хмельницькому районі та місті Переяслав-Хмельницький Київської області.

Одне з найстаріших видань не тільки на Київщині, але й в Україні. Перший номер газети вийшов друком 7 жовтня 1925 року, тоді вона називалась «Змичка».

Загалом за час свого існування газета мала шість назв:

1925-1930 - «Змичка»;

1930-1941 - «Колективіст Переяславщини»;

1943-1951 - «Прапор Переяслава-Хмельницького»;

1951-1963 - «Зоря комунізму»;

1963-1991 - «Комуністична праця»;

з 1991 - «Вісник Переяславщини». 
У різний час газету очолювали Федір Машовець, Поліна Іллічова, Василь Шимченко, Давид Швидкий. Тривалий час видання редагували неординарні особистості Володимир Литовка, Михайло Пасенюк. Під час їхньої роботи газета була цікавою і популярною. Під керівництвом Михайла Пасенюка видання досягло рекордного тиражу - 16,6 тисячі примірників.

31993 по 2001 рік видання редагував Анатолій Розсоха, на цьому посту він отримав звання Заслуженого журналіста України. 3 травня 2001 року редактором газети є Галина Карпенко, яка активною журналістикою займається понад тридцять років, працює в редакції 3 1978-го. За час іiі керівництва в газеті зріс тираж.

На сьогодні «Вісник Переяславщини» виходить щотижня на 24 сторінках формату А-3 (в тому числі 8 сторінки повно кольорові). Газета «Вісник Переяславщини» позиціонує себе як видання для сімейного читання, розрахована на найширшу аудиторію.

Нині в редакції працюють 13 осіб: редактор - Галина Карпенко; відповідальний секретар - Валерій Шкребтієнко; завідувачі відділами - Олена Матвієнко, Юлія Строчинська, Володимир Набок, Валентина Негрей, Леонід Мілютін; кореспондент - Валентина Батрак; дизайнер - Лариса Кононенко; коректор - Віталій Усик; бухгалтер - Наталія Головченко; водій - Олександр Кочубей; офіс-менеджер Ольга Товкач.

У червні 2015 року Національна спілка журналістів України визнала «Вісник Переяславщини» кращою міськрайонною газетою України.

Спробуємо проаналізувати всі назви видання.

Газета «Змичка» (1925 - 1930)

У виданні «Історія міст і сіл Київської області» (Історія 1971:791) газеті «Змичка» присвячено всього кілька слів: «В кінці 1925 року почала виходити газета «Змичка» - орган Переяславського РККП(б)У, райвиконкому та ради профспілок». За довідковими джерелами (каталогами Національної бібліотеки України імені В. І. Вернадського газета «Змичка» виходила з 1925 по 1930 роки. Назва «Змичка» досить популярна у 20-30 роки XX століття, в каталогах 
бібліотеки десятки видань із такою назвою по всій Україні. Газети так називалися на знак єдності союзу робітників та селян.

Переяславської «Змички» ні двадцять п’ятого, ні двадцять шостого років у каталозі національної бібліотеки немає. Серед розділів немає «районні газети», є «окружні» та «стінні». Каталог фіксує тільки 1927 рік і класифікує газету як стінну. У бібліотечних фондах зберігається тільки три номери з грифом «архівний примірник».

«Змичка» у твердій сучасній обкладинці форматом близьким до формату А2. Папір усіх трьох примірників різний за кольором: жовтий, зелений та рожевий. Текст розміщений тільки 3 одного боку аркуша, оскільки газета вважається стінною - іiі розміщували на дошках оголошень, у приміщеннях тощо.

На кожному з примірників зазначено, що це двотижнева стінна газета Райкому КП(б)У та райвиконкому. Третій рік видання. Ціна номера - 5 копійок. Тираж двох номерів по 150 примірників, третього - 175. Редагує газету - ред. колегія. Адреса редакції: Переяслав, Київської округи, Райсельбуд. У кожному номері зверху в рамочці повідомляється: «Кожна сільрада, сельбуд та хата-читальня в районі одержує примірник стінгазети «Змичка» безплатно». Водночас зазначається, що передплата приймається від різних установ та організацій.

Найдавніший примірник переяславської «Змички» у фондах національної бібліотеки за 27 травня 1927 року (п’ятниця, № 8 (35)). На всю полосу видання гасло: «В міжнародний дитячий тиждень більше уваги піонерам!» Відповідно - й публікація про дітей у зв'язку з датою. Автор статті підписався: Р.Д.Б. Крім абревіатур, $є$ й повні: В.П. Підвальний, але переважають псевдоніми: Тихий, Береговий, Чміль, Вибух, Оса та ін. (Змичка, 1927: вип. 17 (44)). Щодо псевдонімів, то редакція зауважує: «Ваш псевдонім редакція нікому не видає, крім прокурора або нарсуду» (Змичка, 1927: вип. 17 (44)).

Більшість публікацій номера - це дописи із сіл, зокрема про події в кооперації. Заголовки свідчать про тематику матеріалів: «Зменшення цін в Козинцях», «Не кооперація, а обдерація» або «Сільрада милує всіх» та ін. 
Примірник газети за 14 жовтня 1927 року, пятниця, № 15 (42) (Змичка, 1927: вип. 15 (42)) повністю прицрочений до жовтневих свят. Газета запрошує сількорів писати про підготовку до них. В одній із публікацій зазначається: «Крім друкованих центральних газет, у нас трудящі самі видають стінні газети, які згуртовують біля себе та виховують нові кадри наших писак - робітників та селян... Газета в руках трудящих - величезне досягнення, яке треба показати, святкуючи десяті роковини Жовтня» (Змичка, 1927: вип. 15 (42)). Огляд цього номера свідчить, що тематика публікацій у газеті розширюється: пояснюється завдання і значення ощадних кас, викривається таке негативне соціальне явище як п'янство, зокрема вживання самогону, піднімаються ветеринарні питання тощо.

Номер за 7 листопада 1927 року, № 17 (44), є ще пафоснішим за закликами (Змичка, 1927: вип.17 (44)). Наприклад, гасло через всю газету: «Десять років переможної боротьби й будівництва соціалізму в СРСР є запорука перемоги світового пролетаріату. Хай живе Перше десятиріччя Жовтня!».

Проте тут публікації не тільки про ювілей Жовтня. $€$ добірка 3 історії: про петлюрівщину, господарювання денікінців, проводиться аналіз сільського господарства Переяславщини, навіть подана порівняльна таблиця орних площ за роками і культурами, наголошується також, що укр. неписьменність у нас неліквідована, зокрема: «Українізація охопила апарати міста й села, секретарі сільрад, співробітники сіл, кооперації тощо - всі пройшли через іспити. Навіть лісники акуратно бувають на іспитах і з трудом виводять своїми корявими руками українські каракулі» (Змичка, 1927: вип.17 (44)).

У номері є гасло й тематичне - освітянське: « Нехай живе наука, що служить пролетарській революції, нехай живе пролетарська революція, що забезпечує справжній розквіт науки!» (Змичка, 1927: вип.17 (44)) і такий аналіз галузі: «Учительству доводилося працювати в надмірно тяжких умовах: шукання методів роботи в новій трудовій школі, відсутність підручників, повна відсутність педлітератури, відсутність педкерівникв шкідливо відбивалося на настрої 
робітників... Успіх роботи залежав від того, як кожний окремий керівник освітньої установи умів зорієнтуватися в тих умовах, що він опинився. Відсоток охоплення дітей шкільного віку досягає 70 - низький для наших умов» (Змичка, 1927: вип. 17 (44)).

Складно за трьома номерами робити загальні висновки про газету «Змичка», яка виходила понад п’ять років, але окремі спробуємо зробити. Схоже, що тільки перша стінна газета виходила таким великим форматом, оскільки у всі наступні роки формат нашої газети був меншим. Хоча минуло майже сто років, але помітний і зараз якісний переяславський друк, такою якістю може похвалитися не кожне сучасне видання. Щодо оформлення газети, то в ній немає фотографій, але є рамочки, лінійки, подаються не тільки заголовки, але й рубрики. Тематика видань надзвичайно широка, але чітко простежується перевага сільськогосподарської тематики, а також тем, що стосується проблем саме жителів сіл.

Крім закликів, лозунгів i позитивних матеріалів, знаходиться місце для критики і вона досить ефективна та резонансна. Що цікаво, більшість авторів публікується під псевдонімами, які $є$ не нейтральними, а виразно маркованими.

Замість великої літери «і» часто використовують знак оклику, а замість «ї» пишуть «і». Але це відповідні друкарські нюанси, а загалом у трьох номерах газети практично немає помилок.

Газета «Колективіст Переяславщини» (1930-1941)

Назву «Колективіст Переяславщини» газета мала з 1930 по 1941 рік. В архівних відділах Національної бібліотеки імені В. I. Вернадського зберігаються підшивки газет починаючи 3 тридцять другого - закінчуючи сорок першим, власне, до початку війни. Практично на всіх цих примірниках газет позначки чорнилом: «Харків. Українська книжкова палата». Саме звідти було передано чимало газетних фондів до національної бібліотеки.

Формат «Колективіста Переяславщини» А3. У 1932 році тираж видання становив 4000 примірників. Це була газета райкому КП(б)У, Р.В.К., райпрофради та колгосп спілки. У 1935 році вона стає органом Переяславського РПК, РКК. Адреса 
редакції: Переяслав, вул. Одинця, № 31, а в 1936 році вул. Шевченка, № 46.

Виходив «Колективіст Переяславщини» двічі на тиждень: у вівторок і суботу. Видання мало дві полоси, редактор М. Народицький. Це з початку 1932 року, а потім виконував обов'язки редактора Білохонь, пізніше і до кінця року - В. Бруч. У 1935-1936 роках газету редагує В. Остратенко, потім заступники редактора Нестеренко, А. Пікулик. У газеті в різні роки було й по дві полоси, іiі тираж становив від двох до чотирьох тисяч, а до кінця 1936 року він зріс до 5650 примірників.

На сторінках газети постійно повідомляється, що передплату приймають пошти та листоноші. Передплатна ціна на 6 місяців - 1 крб. 50 коп., можна здійснити передплату і на три місяці, і на один.

Найширше в «Колективісті Переяславщини» представлені сільськогосподарська та продовольча теми. Практично в кожному номері газети проголошується боротьба «із соціальними хворобами». Про це свідчать заголовки: «Розікрали посівний матеріал» чи «Перша наука чистки».

Виступи газети є досить дієвими, скажімо, в рубриці «Слідами матеріалів» пишуть: «На допис «Хто прийме породіллю?» прокуратура повідомляє, що факти підтвердилися. За недбале ставлення до колгоспниці лікарю Карнауху та акушерці Мусик оголошено догану із занесенням до трудового списку.

Є в газеті тридцятих років карикатури. Центральними фотографіями номерів стали портрети кращих колгоспників.

Різних газет сорок першого року в каталозі бібліотеки чималий перелік. Чого не скажеш про сорок другий та наступні воєнні роки. Останній номер сорок першого року - 27 червня. У цьому році газета виходила на двох полосах форматом А3 у вівторок, середу, п'ятницю, суботу та неділю. Змінилася адреса редакції. Тепер - на вулиці Шевченка, 60. Видання - орган Переяславського райкому КП(б)У і районної Ради депутатів трудящих Київської області. У січні 1941 року газету редагує заступник редактора П. Іллічова, а з лютого до початку війни М. М. Саливон. 
Із публікацій в газеті стає відомо про стінні газети в селах. Повідомлення про війну 3'явилося в номері за 23 червня. Вийшов екстренний номер на двох сторінках формату А4 3 виступом В. М. Молотова. Кілька номерів, які вийшли від початку війни, були насичені матеріалами радянського Інформбюро та публікаціями воєнної тематики.

Для періоду виходу газети «Колективіст Переяславщини» вже характерні певні поліграфічні здобутки: є фотографії, як портретні, так і сюжетні, виділення різими шрифтами, різноманітні відбивки лінійками та вміщення таблиць, зявилися грфічні малюнки. Крім передовиць, більшість публікацій невелика за обсягами. Щодо підписів, то є й псевдоніми, але вже позитивно конотовані: Переможець, Довгий, Борисенко IX, але в переважній більшості - це справжні прізвища, часто із зазначенням посад громадських кореспондентів. Якщо в двадцяті роки газети навіть учили, як писати авторам, то в тридцяті до видання пишуть всі - від доярки до голови парторганізації.

У різних підшивках є практично всі газети. Це дає змогу простежити тираж, який «стрибав» навіть протягом року по кілька разів. Досить часто мінялися редактори газети, так же як і логотип назви видань. У тематиці хоч і переважало сільське господарство, але подавалися новини з Москви, міжнародні повідомлення, були й публікації на літературні теми або навіть пізнавальні, скажімо, про сонячне затемнення 19 червня 1936 року тощо.

Таким було видання до війни. У наступні роки газета в каталозі національної бібліотеки з'являється лише в сорок четвертому, але вже як «Прапор Переяслав-Хмельницького». (1943-1951)

$\ll \Pi$ inop

Переяслава-Хмельницьького»

За довідковим виданням з 1941-1943 років газета на Переяславщині не виходила (Періодичні, 1965: 576) . Газета «Прапор Переяслав-Хмельницького» поновлює свій вихід 3 № 11943 року. Видання - орган Переяслав-Хмельницького РК КП(б)У та Райради депутатів трудящих, тираж - 1050 примірників. Описано за № 3 (7) від 27.01.1944 року (Періодичні, 1965: 576). 31946 року має періодичність 8-9 разів на місяць і тираж 2500 примірників. 
У каталозі газетного відділу Національної бібліотеки України імені В. І. Вернадського газета «Прапор ПереяславХмельницького» датується 1944 роком, але жодного примірника на замовлення виконано не було. Листок замовлення повернули 3 поміткою: «В архівних фондах не знайдено». Були доставлені видання 1945 року і всіх наступних номерів до 1951 року включно.

У 1946 році «Прапор Переяслав-Хмельницького» виходить двічі на тиждень, ціна номера - 15 копійок. Кілька перших номерів видаються на чотирьох полосах, всі наступні на двох. Протягом року газету редагує Поліна Іллічова, детальніше про редакторку йдеться у книзі «Від «Змички» до «Вісника» (Вісімдесят, 2005: 76). Адреса редакції: вул. Шевченка, 58.

Газета після війни помітно відрізняється від попередніх меншою кількістю сторінок, відсутністю фотоілюстрацій, якщо фото і $є$, то воно єдине на всю газету. Переважно - це портрети Леніна або Сталіна (Прапор, 1946: вип. 14-15 (182)). Взагалі оформлення газети досить примітивне, не вирізняються глибоким змістом і тексти.

У виданні чітко простежується тема виборів, зокрема до Верховної Ради УРСР, провідною темою на сторінках видання залишається тема сільського господарства, але через призму суспільного режиму. Особливе місце в газеті «Прапор Переяслав-Хмельницького» належить календарним святам радянської епохи. Публікації про події в місті нечасті, але трапляються, тематика різна. Широко представлені в газеті публікації про комсомольське життя і переважно вони мають критичний характер.

Серед авторів газети «Прапор ПереяславХмельницького» - громадські автори. Це в основному директори різних установ та організацій, партійні лідери, інші посадовці. Їхні посади завжди вказані: агітатор В. Завойко, рахівник Г. Остапенко та ін. Прізвища без посад - журналісти редакції: С. Бойченко, М. Бережний, М. Петрашенко, А. Козлов та ін. Варто зауважити, що здебільшого автори матеріалів чоловіки, хоча це й післявоєнний період. 
Практично в кожному номері - оди Сталіну. Подає «Прапор Переяслав-Хмельницького» новини 3 усього Радянського Союзу, а також міжнародні новини із соціалістичних країн. Нерідко ці повідомлення супроводжуються прес-кліше ТАРС. Є новини і культурного життя. Наприклад, про драматичні театри або вірші відомих письменників з розповідями про них. Але вся ця тематика займає досить малі площі порівняно із політичною та сільськогосподарською тематикою.

На кінець п’ятдесятих газета «Прапор ПереяславХмельницького» починає виходити тричі на тиждень, але все ще на двох полосах. Видання в один час редагує А. Грабовський, тимчасово підписують видання I. Доброскок, В. Григоренко. Тираж газети залишається незмінним - 2500 примірників.

Із огляду на попередні назви видання та навіть забігаючи на перед, можна зробити висновок, що період видання з назвою «Прапор Переяслав-Хмельницького», був для газети найбіднішим як за обсягом, так за змістовою насиченістю та оформленням. Протягом 1943-1951 років газета зовсім не розвивалася, вона відображала тільки соціалістичні змагання та партійне життя, оспівувала особу Сталіна, була переповнена постановами та закликами партії, вона рідко публікувала матеріали про людей та їхні фотографії. Іноді змінювався логотип назви, але не змінювалася його концепція. Малу кількість сторінок і примітивну поліграфію можна пояснити післявоєнною бідністю, але бідність тем і відсутність аналізу дійсності віддзеркалює реалії тоталітарного сталінського режиму.

Міжрайонна газета «Зоря комунізму» (1952-1963) як видання Переяслав-Хмельнищького, Баришівського, Згурівського та Яготинського районів

«Зоря комунізму»- це, по суті, новий етап у розвитку видання на Переяславщині. Оскільки в цей період у газети зростає обсяг, згодом збільшується тираж, різноплановішою стає іiї оформлення. Із цією назвою газета виходила з 1952 по 1963 роки, хоча останні два роки виходу були особливими для «Зорі комунізму». 
У п’ятдесятих роках газета $є$ органом ПереяславХмельницького РК КП (б)У та районної Ради депутатів трудящих Київської області (Зоря, 1952: вип. 86 (878)). У цей період ціна газети - 15 копійок.

У вихідних даних «Зорі комунізму» вже зазначається місце друку газети - Переяслав-Хмельницька друкарня Київського обласного управління у справах поліграфії та видавництва. Редагує газету в 1952 році Василь Шимченко (Вісімдесят, 2005: 6). Газета має формат А3 на двох полосах тиражем 2500 примірників. До кінця року газета збільшує обсяг до чотирьох сторінок, всього за рік вийшло 104 номери. У шістдесятих роках газету редагують Давид Швидкий, Олексій Федорченко, Володимир Литовка (Вісімдесят, 2005: 7-8).

На сторінках газети «Зоря комунізму» $\epsilon$ «постійна присутність» Сталіна, ведеться рубрика «По містах та селах Київщини та України», надзвичайно пафосно подаються інформації про партійні заходи та різноманітні зібрання, для газети характерні сатиричні публікації та ілюстрації. Постійною у виданні є ленінська тематика, провідною темою залишається сільське господарство, газета $є$ агітатором з будьяких питань, з'являються фотографії та текстівки на тему дозвілля. Особливе місце на сторінках «Зорі комунізму» відводиться святам радянського періоду, подаються фотографії передовиків, журналісти пишуть нариси. Щодо імен, то в газету пишуть: Л. Котляр, В. Никифорів, О. Чичикало, а також громадські автори: Т. Левченко, голова промартілі; Т. Жук, сількор; П. Степанченко, колгоспник; Т. Красюк, секретар парторганізації автотранспортної контори та ін. Періодично в газеті друкуються міжнародні новини.

Між обов’язковими примірниками «Зорі комунізму» в підшивках шістдесятих років трапляються газети формату А4 на двох полосах, які виходили в селах району. Під час дослідження були виявлені газети «Вперед» Єрківецької артілі та «Дніпрова зірка» артілі «Шлях Леніна» міста ПереяславХмельницького

«Зоря комунізму» відзначається поступовим збільшенням кількості і різноманіттям жанрів, у газеті збільшується 
кількість фотографій, ведуться постійні рубрики. Оформлення газети поступово стає якіснішим та яскравішим, але фотознімки та заголовки залишаються малого розміру. У газеті практично немає помилок.

Окремим етапом в історії газети є їі видавництво в Яготині. Починаючи з 1962 року, після адміністративних реформ, почала виходити одна, спільна газета на ПереяславХмельницький, Яготин, Березань, Баришівку, Згурівку. Редакція «Зорі комунізму», яка розповсюджувалася в названих містах та прилеглих селах, знаходилася в Яготині за адресою: вул. Пирятинська, 1. Тираж газети становив у різний період від 9 до 12 тисяч примірників. Редагував газету переяславський редактор Володимир Литовка (Вісімдесят, 2005: 8). Видання в цей період виходить як орган Київського обкому КП України та виконкому обласної ради депутатів трудящих по Яготинському територіальному виробничо-колгоспнорадгоспному управлінні. Таку газету в той час можна було придбати за 2 копійки, вона виходила тричі на тиждень на чотирьох полосах.

Яготинська «Зоря» - це час розгорнутого нарису. Простежується в газеті «кукурудзяна» тема, поряд з нарисами з'являються великі за розміром портрети, подаються також фотоілюстрації природи. До 1963 року газета виходить стабільно, без перерв, у підшивках є всі номери.

\section{Газета «Комуністична праця" (1963-1991)}

Під новою назвою - «Комуністична праця» - районна газета почала виходити з 1963 року. Це був рік реорганізації, коли видання, яке певний період видавалося в Яготині, знову повертається до Переяслава, тому перший номер газети вийшов тільки 26 березня 1963 року. У вихідних даних зазначалося: «Рік видання - 1-ий». Схоже на претензії повного оновлення не тільки «вивіски», але й самої історії друкованого видання. Офіційно він уже значився як «орган партійного комітету Переяслав-Хмельницького виробничого колгоспнорадгоспного управління та районної ради депутатів трудящих Київської області» (Комуністична, 1963: вип. 1).

У Переяславі «Комуністичну працю» продовжує редагувати Володимир Литовка, але тираж її через звуження 
регіону розповсюдження від кількох районів до одного зменшується від 9-12 тисяч до 6-6,5 тисяч примірників. Періодичність і обсяг залишаються тими ж - чотири газетні шпальти по вівторках, четвергах і суботах. Передплатна ціна місяць становила 19 копійок.

Відслідковуючи вихідні дані газети періоду 60-70-х років, у око впадає неоднозначність позиції щодо визначення віку самого видання. Починаючи з 1963 з «нульового» старту, до травня 1965 року ще друкують «рік видання 3-ій», а вже наступного місяця зазначається «рік видання 32-ий». 3 другої половини 70-х років про родовід газети констатують: «газета виходить з жовтня 1930 року». Що, як свідчать джерела, було помилкою.

Із січня 1965 року «Комуністична праця» стає органом Переяслав-Хмельницького райкому КП України та районної Ради депутатів трудящих Київської області, пізніше переходить під юрисдикцію міського комітету Компартії, і майже відразу ж потому, з 1966 року, стає органом Переяслав-Хмельницького районного комітету КП України та районної ради депутатів трудящих Київської області.

Подібні трансформації позначаються на тематиці висвітлювання тем та подій, на визначенні пріоритетів інформації. Автори вже пишуть не тільки про сільське життя, чимало інформації надходить і з міста, значно побільшало публікацій суспільно-партійного змісту, причому, всесоюзного масштабу.

1976 рік - $з$ березня «Комуністична праця» виходить чотири рази на тиждень: вівторок, середа, п’ятниця, субота. Цього року тираж зростає до 12,5 тисячі примірників. Друкується в переяславській друкарні. Ціна одного примірника -2 копійки.

Верстка газети за 28-річний період життя як «Комуністичної праці» нерідко змінювалася, найбільше експериментували з логотипом назви, тобто дизайном назви та iii місцем розташування.

Увесь свій «комуністичний період» видання яскравіє багатством різнопланових доволі якісних фотографій, малюнків, колажів, графіки. Оскільки «народ і партія єдині», 
то відповідна тематика з образами різних вождів - пріоритетна, їх постачає газеті РАТАУ. Власні фото приваблюють динамічністю, цікавими сюжетами, різноманітністю гарних облич, на більшості цих портретів - рядові трудівники, усміхнені, щасливі. Починаючи з 1966 року, перші сторінки газети до великих державних свят виходять у кольорі червоному, рідше зеленому чи синьому.

Характер «Комуністичної праці» завжди віддзеркалював загальнодержавні настрої і політичну спрямованість суспільства. За часів «хрущовської відлиги» видання було найбільш цікаве, гостре, актуальне і багатогранне. Величезна кількість тем і рубрик, наприклад тему про створення власного герба Переяслава місцеві історики порушували ще наприкінці 60-x p.

У 60-х роках до редакції приходять люди, які стануть іï кістяком на довгі роки - Володимир Литовка, Михайло Пасенюк, Микола Палагута, Микола Назаренко. Саме ці кадри виростили нову генерацію журналістів, які прийшли в редакцію у 80-х: Галину Карпенко, Миколу Михняка, Анатолія Розсоху, Юрія Розовика, Леоніда Мілютіна.

Суспільно-політичний застій в державі періоду 80-х років відгонить на шпальтах газети. Партійно-ленінський пафос стає домінантою в тематиці і пріоритетною щодо місця розміщення і розмірів публікацій.

I хоча останні роки в образі «Комуністичної праці» (аж до осені 1990 року) видання проживало в дусі радянського будівництва, все ж журналісти час від часу знаходили можливість написати і людські матеріали.

Щодо збору матеріалу про переяславське видання, то це було найсистемніше і найефективніше, оскільки журналісти вже «Вісника Переяславщини» у 2005 році до 80-річчя газети видали книгу «Від «Змички» до «Вісника» 3 дослідженнями про історію газети (Вісімдесят, 2005: 76). Наступні розвідки про пресу Лівобережжя Київщини доводилося по крихтах збирати в довідникових виданнях, у редакціях газети, навіть у спогадах журналістів тощо.

Висновки та перспективи подальших досліджень. Отже, газета «Вісник Переяславщини» упродовж всієї майже 
сторічної історії $є$ достовірним джерелом для вивчення суспільно-політичного устрою, тематики, поліграфічної та правописної сфер, історичних постатей Переяславщини та тих осіб, що відвідували район.

Ми ж в авторській перспективі бачимо періодику Переяславщини як джерело історії української археології і не тільки.

\section{ДЖЕРЕЛА ТА ЛІТЕРАТУРА}

1. Від «Змички» до «Вісника». Вісімдесят років життя газети. Переяслав-Хмельницький. Вісник Переяславщини. 2005. 76 c.

2. Змичка. Вип. 15 (42). Переяслав. 14 жовтня 1927.

3. Змичка. Вип. 17 (44). Переяслав. 7 листопада 1927.

4. Змичка. Вип. 8 (35). Переяслав. 27 травня 1927.

5. Зоря комунізму. Вип. 1. 1 травня. 1962.

6. Зоря комунізму. Вип. 86 (878). 26 жовтня. 1952.

7. Історія міст і сіл Української РСР: В 26 т. Київська область / Ред. кол. тома: Рудич Ф. М. (гол. редкол.), Бакуменко П. І., Бачинський П. П., Борщ Ю. Ф., Гуслистий К. Г., Кононенко В. І., Корольов Б. І. (заст. гол. редкол.), Майстренко А. А. (відп. секр. редкол.), Макаренко Г. К., Марченко М. I., Панін Я. Г., Петренко М. 3., Пшеничний Г. С., Саженюк С. Н., Сергієнко Г. Я., Слабєєв І. С., Тихолаз Г. А., Шевченко Ф. П., Шморгун П. М. АН УРСР. Інститут історії. К.: Голов. ред. УРЕ АН УРСР, 1971. $791 \mathrm{c.}$

8. Колективіст Переяславщини. Вип. 118 (287). Переяслав. 20 листопада.1932.

9. Колективіст Переяславщини. Вип. 27 (2149). Переяслав. 8 лютого. 1941.

10. Колективіст Переяславщини. Вип. 5 (2141). Переяслав. 5 січня 1941.

11. Комуністична праця. Вип. 1. 26 березня. 1963.

12. Періодичні видання УРСР 1917-1960 : газети : бібліографічний довідник / редакційна колегія : В.М. Скачков, M.I. Багрич, А.І. Козлова ; Державний комітет ради Міністрів УРСР по пресі, книжкова Палата УРСР. Харків : Редакційновидавничий відділ книжкової Палати УРСР, 1965. 576 с. 
13. Прапор колективіста. № 57 (86). Баришівка. 3 серпня 1931.

14. Прапор Переяслав-Хмельницького. Вип. 14-15 (182). Переяслав. 14 лютого 1946.

15. Прапор Переяслав-Хмельницького. Вип. 3 (75). Переяслав. 11 січня 1945.

16. Прапор Переяслав-Хмельницького. Вип. 51 (124). Переяслав. 19 липня 1945.

\section{REFERENCES}

1. Vid «Zmychky» do «Visnyka» 2005. Visimdesyat rokiv zhyttya hazety. Pereyaslav-Khmel'nyts'kyy. Visnyk Pereyaslavshchyny. $76 \mathrm{~s}$ [in Ukrainian].

2. Zmychka 1927. Vyp. 15 (42). Pereyaslav. 14 zhovtnya[in Ukrainian].

3. Zmychka 1927. Vyp. 17 (44). Pereyaslav. 7 lystopada [in Ukrainian].

4. Zmychka 1927. Vyp. 8 (35). Pereyaslav. 27 travnya [in Ukrainian].

5. Zorya komunizmu 1962. Vyp. 1.1 travnya [in Ukrainian].

6. Zorya komunizmu 1952. Vyp. 86 (878). 26 zhovtnya [in Ukrainian].

7. Istoriya mist i sil Ukrayins'koyi RSR 1971: V 26 t. Kyyivs'ka oblast' / Red. kol. toma: Rudych F. M. (hol. redkol.), Bakumenko P. I., Bachyns'kyy P. P., Borshch Yu. F., Huslystyy K. H., Kononenko V. I., Korol'ov B. I. (zast. hol. redkol.), Maystrenko A. A. (vidp. sekr. redkol.), Makarenko H. K., Marchenko M. I., Panin Ya. H., Petrenko M. 3., Pshenychnyy H. S., Sazhenyuk S. N., Serhiyenko H. Ya., Slabyeyev I. S., Tykholaz H. A., Shevchenko F. P., Shmorhun P. M. AN URSR. Instytut istoriyi. K.: Holov. red. URE AN URSR, $791 \mathrm{~s}$ [in Ukrainian].

8. Kolektyvist Pereyaslavshchyny 1932. Vyp. 118 (287). Pereyaslav. 20 lystopada[in Ukrainian].

9. Kolektyvist Pereyaslavshchyny 1941. Vyp. 27 (2149). Pereyaslav. 8 lyutoho [in Ukrainian].

10. Kolektyvist Pereyaslavshchyny 1941. Vyp. 5 (2141). Pereyaslav. 5 sichnya [in Ukrainian]. 
11. Komunistychna pratsya 1963. Vyp. 1. 26 bereznya [in Ukrainian].

12. Periodychni vydannya URSR 1917-1960, 1965 : hazety : bibliohrafichnyy dovidnyk / redaktsiyna kolehiya : V.M. Skachkov, M.I. Bahrych, A.I. Kozlova ; Derzhavnyy komitet rady Ministriv URSR po presi, knyzhkova Palata URSR. Kharkiv : Redaktsiynovydavnychyy viddil knyzhkovoyi Palaty URSR, 576 s [in Ukrainian].

13. Prapor kolektyvista 1931. № 57 (86). Baryshivka. 3 serpnya [in Ukrainian].

14. Prapor Pereyaslav-Khmel'nyts'koho 1946. Vyp. 14-15 (182). Pereyaslav. 14 lyutoho [in Ukrainian].

15. Prapor Pereyaslav-Khmel'nyts'koho 1945. Vyp. 3 (75). Pereyaslav. 11 sichnya [in Ukrainian].

16. Prapor Pereyaslav-Khmel'nyts'koho 1945. Vyp. 51 (124). Pereyaslav. 19 lypnya [in Ukrainian].

\section{АНОТАЦІЯ}

Періодичні видання виходять через певні проміжки часу, має заздалегідь визначену постійну щзорічну кількість $і$ назву нумерованих чи датованих, однотипово оформлених випусків, які не повторюються за змістом, мають однакову назву. Особливо иіккаві для істориків, зокрема краєзнавиів, регіональні видання. Такі видання містять низку різноманітної інформації.

Мета статті - проаналізувати історичні етапи розвитку видання Переяславщини упродовж майже столітньої історії, окреслити вихід видання за всіма назвами, щзо змінювалася шість разів, зроблено загальний огляд газет за довідковою літературою та примірниками газет.

У статтідля вивчення історії та розвитку видань Переяславщини упродовж XX-початку XXI cm. використано як основні метод спостереження та описовий метод. На різних етапах дослідження послуговувалися методом функиіонального аналізу для визначення тематичного навантаження періодичних видань.

У проиесі дослідження застосовано такі методи: метод аналізу та синтезу - на етапі членування текстів періодичного видання Переяславщиини та групування їх за 
певними ознаками; метод квантитативного аналізу - задля визначення частотності використання рубрик $i$ ï різноманітних форм в на газетних полосах.

Загалом за час свого існування газета мала шість назв: 1925-1930 - «Змичка»; 1930-1941 - «Колективіст Переяславщини»; 1943-1951 - «Прапор ПереяславаХмельницького»; 1951-1963 - «Зоря комунізму»; 1963-1991 «Комуністична прачяя»; з 1991 - «Вісник Переяславщчини».

Зроблено висновок, щуо газета «Вісник Переяславщини» упродовж всієї майже сторічної історії $\epsilon$ достовірним джерелом для вивчення суспільно-політичного устрою, тематики, поліграфічної та правописної сфер, історичних постатей Переяславщини та тих осіб, щзо відвідували район.

Ми ж в авторській перспективі бачимо періодику Переяславщчини як джерело історії украӥнської археологї $і$ не тільки.

Ключові слова: «Вісник Переяславщчини,, регіональне видання, назви газет, видавець газети, журналіст, громадський автор.

\section{АННОТАЦИЯ}

Периодические издания выходят через определенные промежутки времени, имеет заранее определенную постоянную ежегодное количество и название нумерованных или датированных, однотипно оформленных выпусков, которые не повторяются по содержанию, имеют одинаковое название. Особенно интереснь для историков, в частности краеведов, региональные издания. Такие издания содержат ряд разнообразной информацчии.

Цель статьи - проанализировать исторические этапь развития издания Переяславщчины на протяжении почти столетней истории, определить выход издания по всем названиям шесть раз, сделан общиий обзор газет по справочной литературе и экземплярам газет.

В статье для изучения истории и развития изданий Переяславщчины протяжении $X X-$ начала XXI в. использовано в качестве основных метод наблюдения и описательный метод. На разных этапах исследования пользовались методом 
функиионального анализа для определения тематического нагрузки периодических изданий.

В проиессе исследования применены следующие методы: метод анализа и синтеза - на этапе членения текстов периодического издания Переяславщины и группировка их по определенным признакам; метод квантитативного анализа для определения частотности использования рубрик и их различных форм в на газетных полосах.

Всего за время своего существования газета имела шесть названий: 1925-1930 - «Змичка»; 1930-1941 «Колективіст Переяславщчни»; 1943-1951 - «Прапор Переяслав-Хмельницького»; 1951-1963 - «Зоря комунізму»; 1963-199 - «Комуністична працяя; с 1991 - «Вісник Переяславичини».

Сделан вывод, что газета «Вісник Переяславщини» в течение всей почти столетней истории является достоверным источником для изучения общественнополитического строя, тематики, полиграфической $и$ правописной областей, исторических лиц Переяславщчины и лиц, посещавших район.

$\mathrm{Mbl}$ же в авторской перспективе видим периодику Переяславщчины как источник истории украинской археологии и не только.

Ключевые слова: «Вестник Переяславщины», региональное издание, названия газет, издатель газеть, журналист, общественный автор. 
ДЛЯ НОТАТОК 